\title{
NAUCZANIE LEKSYKI SPECJALISTYCZNEJ W MIECDYNARODOWYM CENTRUM KSZTAŁCENIA POLITECHNIKI KRAKOWSKIEJ W GRUPACH NA POZIOMACH PODSTAWOWYCH A1 I A2 (NA PRZYKLADZIE SŁOWNICTWA Z DZIEDZINY ARCHITEKTURY I HISTORII SZTUKI)
}

Słowa kluczowe: słownictwo specjalistyczne, poziom podstawowy A1 i A2, architektura, historia sztuki

Streszczenie. Artykuł prezentuje „model” nauczania słownictwa specjalistycznego w grupach na poziomie podstawowym A1 i A2, wypracowany w Międzynarodowym Centrum Kształcenia Politechniki Krakowskiej ${ }^{1}$. Został on przedstawiony na podstawie kursów leksyki architektonicznej oraz leksyki z dziedziny historii sztuki. Najważniejsze informacje dotyczące ich organizacji przedstawiono w pierwszej części tekstu. Dalsze fragmenty zostały poświęcone roli tekstu na zajęciach specjalistycznych, wykorzystywanym technikom nauczania oraz przykładowym zadaniom. Artykuł kończy opis trudności pojawiających się w czasie nauczania wspomnianego typu słownictwa w grupach początkujących oraz krótki opis sukcesów absolwentów kursu przygotowującego obcokrajowców do podjęcia studiów w Polsce, realizowanego w MCK PK.

Niniejszy artykuł poświęcony jest nauczaniu słownictwa specjalistycznego w grupach początkujących (na poziomach podstawowych A1 i A2) w Międzynarodowym Centrum Kształcenia Politechniki Krakowskiej ${ }^{1}$. Prezentuje model nauczania studentów cudzoziemców polskiej leksyki specjalistycznej na przykładzie słownictwa architektonicznego i słownictwa z dziedziny historii sztuki².

*egalat@pk.edu.pl,mrittner@pk.edu.pl, Międzynarodowe Centrum Kształcenia Politechniki Krakowskiej, 31-866 Kraków, ul. Skarżyńskiego 1.

${ }^{1}$ Dalej MCK PK.

${ }^{2}$ MCK PK zostało utworzone w $1985 \mathrm{r}$. i początkowo przygotowywało studentów tylko do studiów na kierunku architektura i urbanistyka. Z czasem program jednostki zmienił się, został 


\section{PROGRAM KSZTALCENIA SPECJALISTYCZNEGO W MCK PK}

Zajęcia ze słownictwa specjalistycznego stanowią tylko jeden z elementów składających się na cały obowiązujący studentów MCK PK program kształcenia. Wszyscy studenci deklarujący chęć studiowania na kierunkach architektonicznych od samego początku kursu uczestniczą także w zajęciach z matematyki - niezależnie od poziomu swojej kompetencji językowej. Ponadto obowiązkowe są dla nich zajęcia $z$ budownictwa oraz elementów grafiki inżynierskiej. Osoby kształcące się na profilu architektonicznym biorą też udział w zajęciach z rysunku odręcznego oraz w plenerze rysunkowym w Lanckoronie. Jest to tygodniowy wyjazd studentów wraz z nauczycielami rysunku zakończony wernisażem prac studenckich. Wspomniane wyżej zajęcia prowadzone są przez osoby posiadające specjalistyczne przygotowanie.

W MCK PK słownictwo specjalistyczne wprowadzane jest dla grup z poziomów B1, B2, C1 i C2 od samego początku kursu, tj. od października. W przypadku poziomów A1 i A2 zajęcia ze słownictwa specjalistycznego rozpoczynają się w drugim semestrze. W zależności od liczebności grupy kurs słownictwa specjalistycznego liczy 30 lub 60 godzin - jest to (odpowiednio) jedno spotkanie w tygodniu lub dwa spotkania tygodniowo, każdorazowo po 90 minut. Nieodłączną część zajęć stanowią wycieczki do muzeów, także lekcje muzealne organizowane przez Muzeum Narodowe w Krakowie. Zajęcia ze słownictwa specjalistycznego powierzane są lektorom języka polskiego jako obcego, jednak tylko tym, którzy posiadają przynajmniej podstawową wiedzę z danej dziedziny ${ }^{3}$.

Tradycja nauczania słownictwa z dziedziny historii sztuki jest w MCK PK znacznie krótsza niż tradycja nauczania słownictwa architektonicznego. Kurs historii sztuki jest regularnie organizowany dla grup na poziomie A od $2013 \mathrm{r}$. Liczba studentów biorących udział w tychże zajęciach jest znacznie mniejsza w porównaniu do liczby osób uczących się na profilu architektonicznym - w roku akademickim 2014/2015 grupa składała się z 6 osób i była (jak do tej pory) najliczniejsza ${ }^{4}$. W konsekwencji zajęcia $\mathrm{z}$ historii sztuki odbywają się raz w tygodniu (kurs trzydziestogodzinny). Osoby wybierające ten profil kształcenia w większości rozpoczynają naukę na kierunku konserwacji zabytków lub grafiki. Pochodzą głównie z Mongolii oraz z Ukrainy. W zależności od wybranego przyszłego kierunku studentom oferowane są również inne zajęcia (analogicznie do tego, jak

dostosowany do realnego zapotrzebowania rynku edukacyjnego i rynku pracy. Obecnie Centrum przygotowuje obcokrajowców do studiów na uczelniach o wielu profilach naukowych.

${ }^{3}$ Przykładowo zajęcia ze słownictwa architektonicznego na poziomach A1, A2 prowadzone są przez Edytę Gałat, neofilologa, absolwentkę kursu przewodników po Krakowie odbytego pod kierunkiem prof. Józefa Krasnowolskiego. Na poziomach B i C zajęcia ze słownictwa architektonicznego prowadzone są przez dyrektora Centrum - architekta z wykształcenia.

${ }^{4} \mathrm{~W}$ tym samym roku na kurs słownictwa architektonicznego uczęszczało 27 studentów. 
wygląda kształcenie w obrębie profilu architektonicznego), np. dla przyszłych studentów konserwacji zabytków są to chemia i słownictwo chemiczne.

W celu zaliczenia kursu ze słownictwa specjalistycznego student zobligowany jest do uzyskania pozytywnej oceny z odpowiedzi ustnej, testów cząstkowych, egzaminu połówkowego i końcowego. Prowadzący zajęcia może te wymagania nieznacznie modyfikować - przykładowy końcowy test zaliczeniowy ${ }^{5}$ znajduje się w aneksie.

\section{NAUCZANIE JEZZYKA SPECJALISTYCZNEGO VS NAUCZANIE SLOWNICTWA SPECJALISTYCZNEGO}

Należy zwrócić uwagę na to, że w MCK PK naucza się nie danego języka specjalistycznego $^{6}$, ale specjalistycznej leksyki. Takie rozwiązanie może zostać uznane za dyskusyjne, podyktowane jest jednak względami praktycznymi. Otóż wydaje się, że z punktu widzenia pełnego przygotowania studenta do podjęcia studiów w języku polskim korzystniejsze od nauczania „całego” wybranego języka specjalistycznego (w dużym wymiarze godzin) jest nauczanie większej liczby przedmiotów (w mniejszym wymiarze godzin). Wiąże się to w oczywisty sposób $\mathrm{z}$ tym, iż w czasie pierwszego roku studiów studenci muszą uczestniczyć w różnego typu zajęciach, nie tylko w tych, które wykorzystują jako medium komunikacji jeden język specjalistyczny. Należałoby raczej powiedzieć, że już od początku student jest zobligowany do posługiwania się wieloma językami specjalistycznymi. Można więc stwierdzić, że nauczanie słownictwa, nie zaś języka specjalistycznego, ma w tym przypadku swoje uzasadnienie.

Nie tylko argument natury praktycznej przemawia za nauczaniem wyłącznie leksyki specjalistycznej. Niezwykle istotne jest także to, iż niedostateczne opanowanie przez studenta chociażby konstrukcji składniowych właściwych danemu językowi specjalistycznemu (przy założeniu oczywiście, iż w przypadku tegoż języka zasadne jest ich wyodrębnienie ${ }^{7}$ ) nie uniemożliwia komunikowania się

\footnotetext{
${ }^{5}$ Ze względu na ograniczone ramy niniejszego tekstu zaprezentowany został jedynie jeden końcowy test zaliczeniowy - ze słownictwa architektonicznego.

${ }^{6} \mathrm{Na}$ temat najważniejszych dotychczasowych typologii odmian współczesnego języka polskiego zob. Zdunkiewicz-Jedynak 2013, s. 30-35 (tam też literatura dotycząca tego zagadnienia). Z nowszych publikacji zob. też Malinowska i in. 2013. O języku specjalistycznym szczegółowo piszą Ligara, Szupelak 2012, s. 21-40, a także Gajewska, Sowa 2014, s. 17-26.

${ }^{7}$ Należy podkreślić, iż trudno mówić o wyróżnikach danego języka specjalistycznego w sytuacji, w której brak jest prac językoznawczych opisujących tenże język. Wydaje się, że w zakresie składni języki specjalistyczne po prostu zbliżają się do składni języka naukowego. Zob. jednak np. artykuł M. Chłopickiej-Wielgos, D. Pukas-Palimąki, w którym mowa jest o „składni języka medycznego" (Chłopicka-Wielgos, Pukas-Palimąka 1996, s. 75, 76).
} 
w nim. Inaczej w przypadku nieopanowania leksyki - jak zauważa się w literaturze przedmiotu (Seretny, Lipińska 2005, s. 75), braki leksykalne stanowią w komunikacji barierę, którą niezwykle trudno jest pokonać. Wreszcie to właśnie słownictwo często uznawane jest za jeden z najważniejszych elementów odróżniających język specjalistyczny od języka ogólnego (Ligara, Szupelak 2012, s. 51). Trzeba na koniec dodać, że dla lektora prowadzącego zajęcia specjalistyczne łatwiejsze jest i co ważne - szybsze opracowanie korpusu słów charakterystycznych dla danej dziedziny niż opracowanie wszystkich tych elementów językowych, które stanowią wyróżnik danego języka specjalistycznego.

\section{WYKORZYSTANIE TEKSTU NA ZAJĘCIACH ZE SLOWNICTWA SPECJALISTYCZNEGO}

Zajęcia ze słownictwa specjalistycznego mają na celu nie tylko nauczanie leksyki właściwej dla danej dziedziny, ale także przekazanie podstawowej wiedzy z tejże dziedziny. Zajęcia koncentrują się wokół czytania, wyjaśniania i komentowania tekstu, choć studentom proponowane są także inne formy aktywności, takie jak: samodzielne studiowanie opracowanych przez prowadzącego skryptów, materiałów dostępnych na platformie PK Moodle (http://elf2.pk.edu.pl/course/view. php?id=736), przygotowanie prezentacji multimedialnej, uczestnictwo w grach autorskich. Tekst stanowi jednak niezwykle istotny element każdych zajęć, co wynika $z$ traktowania go jako bazy form leksykalnych i podstawy informacji z danej dziedziny - zarówno do słów, jak i do wiadomości student może wrócić. Mówiąc inaczej, jest on ,śladem” pozostawianym studentowi po każdych zajęciach. Istotna rola tekstu wynika także z tego, iż kształcenie się na danym kierunku oznacza w dużej mierze kontakt z tekstem. Stwierdzenie to może wydać się oczywiste, jednak praktyka pokazuje, że nie wszyscy uczący się są tego świadomi.

Proponowane studentom teksty powstają często na podstawie tekstów internetowych ${ }^{8}$. Wiąże się to przede wszystkim z ich dostępnością nie tylko dla prowadzących zajęcia, ale także dla studentów, niejednokrotnie nieposiadających nawyku korzystania ze źródeł książkowych. Nie bez znaczenia jest też stosunkowo duża łatwość językowa i pojęciowa tekstów internetowych (poruszają podstawowe dla dziedziny zagadnienia), co stanowi konsekwencję popularnonaukowego, nie zaś ściśle naukowego ich charakteru9. Ważną rolę odgrywa wreszcie

${ }^{8}$ Strony internetowe, z których czerpane są informacje, to np. www.wikipedia.pl, www.historiasztuki.com.pl, www.portalwiedzy.onet.pl. Wykorzystywany w MCK PK skrypt do nauczania słownictwa architektonicznego w grupach początkujących opiera się ponadto na podręcznikach do historii oraz do historii sztuki na poziomie polskiego gimnazjum.

${ }^{9}$ A. Starzec wskazuje na takie cechy stylu popularnonaukowego jak: hybrydyczny charakter tekstów go reprezentujących, polegający na łączeniu cech stylu naukowego, publicystycznego i po- 
wykształcenie osoby prowadzącej zajęcia, która nie zawsze ukończyła studia wyższe z dziedziny, której dotyczy kurs. Wydaje się jednak, że w przypadku zajęć ze słownictwa specjalistycznego dla grup na poziomie podstawowym istotniejsza jest odpowiednia kompetencja w zakresie nauczania języka polskiego jako obcego niż gruntowne przygotowanie z zakresu danej dziedziny wiedzy. Pozwala to bowiem na dopasowanie nauczanego materiału oraz stosowanych technik nauczania do możliwości studentów początkujących ${ }^{10}$.

Mówiąc o tekstach wykorzystywanych na zajęciach z leksyki specjalistycznej, warto także dodać, że zwykle mają one objętość około jednej strony komputeropisu (mniej więcej 320 słów) i dotyczą zagadnień związanych z architekturą (w przypadku kursu słownictwa architektonicznego) lub z architekturą, rzeźbą, malarstwem danej epoki (w przypadku kursu słownictwa z dziedziny historii sztuki). W miarę możliwości (dostępności) wprowadzane są także oryginalne teksty książkowe. Ich pojawienie się na zajęciach ma na celu przede wszystkim pokazanie studentowi, z czym będzie się musiał zmierzyć w czasie swoich studiów. Nie ulega jednak wątpliwości, że zarówno teksty przygotowane przez prowadzącego zajęcia ze słownictwa specjalistycznego, jak i teksty oryginalne są dla studenta na tym etapie nauki języka polskiego trudne ${ }^{11}$.

Poniżej przedstawione zostały dwa przykładowe teksty (oryginalny i przygotowany przez prowadzącego) wykorzystywane w czasie kursu słownictwa specjalistycznego z dziedziny historii sztuki. W tekstach zaznaczone zostały te słowa, które zwykle były dla studentów niezrozumiałe. Pierwszą grupę (słowa wytłuszczone) stanowi leksyka o charakterze terminologicznym, uznana za mieszczącą się w obrębie danej dziedziny ${ }^{12}$. W drugiej grupie (wyrazy podkreślone)

tocznego, przystępność, informacyjna sekundarność (Starzec 2013, s. 85, 86-87). Z kolei U. Żydek-Bednarczuk zwraca uwagę na obecność leksyki wspólnoodmianowej i potocznej w tekstach internetowych (Żydek-Bednarczuk 2013, s. 353).

${ }^{10} \mathrm{Na}$ temat tego, jakie przygotowanie powinna posiadać osoba nauczająca języka specjalistycznego, zob. Lesiak-Bielawska 2015, s. 76.

${ }^{11}$ Przez trudność tekstu rozumie się tutaj przede wszystkim nasycenie tekstu nowymi, a dodatkowo specjalistycznymi (czyli skomplikowanymi pod względem pojęciowym) słowami. Por. Seretny, Lipińska 2005, s. 99-100, Kic-Drgas 2015. Osobne zagadnienie stanowią pojawiające się w tekście te elementy gramatyki, składni, które nie są przewidziane programem nauczania na poziomie A, ale które pojawiają się w tekstach ,specjalistycznych”. Za przykład mogą posłużyć formy bezosobowe czasownika czy imiesłowy przymiotnikowe bierne.

${ }^{12}$ Mówienie o „słownictwie o charakterze terminologicznym”, nie zaś o terminologii jest tutaj celowe. Wiąże się ono bowiem z zagadnieniem wyodrębnienia tych słów, które można by uznać za terminy. Wobec braku literatury językoznawczej, która charakteryzowałaby ,język architektury” i ,język historii sztuki” (jedyną znaną autorkom pracą bezpośrednio odnoszącą się do ,języka architektury” jest praca magisterska M. Przybylskiej (2011), poświęcona jednak nie tyle ,językowi architektury" czy słownictwu architektonicznemu, ile programowi nauczania języka specjalistycznego) oraz wobec braku korpusów słownictwa specjalistycznego (por. Przybylska 2008) wyznaczanie zasobu słów, które musi opanować osoba ucząca się, dokonuje się w praktyce w sposób „chałupniczy" - polega ono na wychwytywaniu przez lektora prowadzącego zajęcia tych słów, które często 
mieszczą się słowa nieodnoszące się co prawda bezpośrednio do danej dziedziny, a więc „nieterminologiczne”, zazwyczaj jednak niezrozumiałe ${ }^{13}$.

Klasyczne świątynie starożytnej Grecji budowano zgodnie z wiarą, że pewne kształty i proporcje są miłe bogom. Istnieją trzy główne antyczne porządki architektoniczne, które różnią się ornamentyką i proporcjami kolumn, głowic (kapiteli) i belkowania, czyli konstrukcji opierającej się na głowicach. Najstarszy jest porządek dorycki, który powstał w VII wieku p.n.e. i występował głównie w Grecji i koloniach zachodnich, na przykład na Sycylii i w południowej Italii. Pokazana poniżej świątynia Posejdona to charakterystyczny przykład tego porządku. Jest ona hypetralna (nieposiadajacca dachu) i perypteralna (otoczona pojedynczym rzẹdem kolumn). Około stu lat później na wyspach Morza Egejskiego wykształcił się bardziej dekoracyjny porządek joński. Jego charakterystyczne cechy to woluty (ślimacznice) na głowicach oraz akroteria (dekoracje frontonu). Porządek koryncki powstał w Atenach w V wieku p.n.e. Można go łatwo rozpoznać po liściach akantu na głowicach. Ten porządek był następnie często stosowany w architekturze starożytnego Rzymu.

(Architektura, seria Ilustrowane stowniki 1994)

Tak samo jak architektura rzeźba klasycystyczna była inspirowana sztuką starożytną. Czasami trudno jest zobaczyć różnicę między rzeźbami starożytnymi a klasycystycznymi. Rzeźba klasycystyczna to rzeźba spokojna i idealistyczna, inspirowana antyczną koncepcją piękna. Dominują kierunki pionowe i poziome. Częstymi rzeźbami są popiersia, nagrobki, pomniki konne, kolumny, łuki triumfalne. Pojawiały się postacie mitologiczne i alegoryczne. Głównym materiałem rzeźbiarskim był biały marmur, powierzchnia rzeźby była gładka.

Ważnymi rzeźbiarzami dojrzałego klasycyzmu byli Antonio Canova (Tancerka, Napoleon, Psyche budzona pocałunkiem Kupidyna, Henryk Lubomirski jako Amor) i Bertel Thorvaldsen (Ganimed, nagrobek Włodzimierza Potockiego na Wawelu, Trzy Gracje i Amor, pomnik Mikołaja Kopernika, pomnik księcia Józefa Poniatowskiego). Canova rzeźbił w marmurze, pokazywał postacie mitologiczne i realne, jednak nawet prawdziwe postacie często nosiły starożytne stroje. Dzięki niemu popularny stał się nowy typ nagrobka - grecka stela i płaskorzeźba osoby płaczącej przed cokołem, na którym znajduje się popiersie zmarłego. Thorvaldsen był nazywany skandynawskim Michałem Aniołem. Jest autorem dzieł mitologicznych, historycznych, religijnych, rzeźb plenerowych, pomników i grobowców. Jego twórczość wywarła duży wpływ na rzeźbę XIX w. ${ }^{14}$.

pojawiają się w tekstach dotyczących danej dziedziny i które, niejednokrotnie intuicyjnie, uznaje się za odnoszące się do „obiektów specyficznych (zarówno obiektów materialnych, jak i pojęć) dla tej dziedziny w sposób - w założeniu - ścisły i jednoznaczny" (Polański 2003, s. 602). Wydaje się zatem, że określenie „słownictwo o charakterze terminologicznym” jest tutaj ,językoznawczo bezpieczniejsze”. Por. także Ligara, Szupelak 2012, s. 51-75.

${ }^{13}$ W MCK PK zajęcia z języka polskiego ogólnego, na każdym poziomie zaawansowania, prowadzone są z uwzględnieniem obowiązującego w jednostce minimum programowego. W związku z tym warto dodać, że znając je, osoba prowadząca po raz pierwszy kurs danego słownictwa specjalistycznego może przypuszczać, które z wyrazów uczący się prawdopodobnie opanowali, a których nie. Dodatkowo wcześniejsze niepojawienie się słowa w czasie zajęć z leksyki specjalistycznej zwiększa prawdopodobieństwo jego nieznajomości (niezrozumiałości) przez studentów.

${ }^{14}$ Tekst powstały na podstawie: B. Osińska, Sztuka i czas. Od klasycyzmu do współczesności, Warszawa 2015; S. K. Stopczyk, Blizej sztuki, Warszawa 2015; http://eszkola.pl/jezyk-polski/ 
Ze względu na trudność ${ }^{15}$ pojawiających się na zajęciach ze słownictwa specjalistycznego tekstów kluczowe znaczenie mają zadania, które tym tekstom towarzyszą. Powinny one być tak skonstruowane, aby po ich wykonaniu student mógł otrzymać swojego rodzaju „bank słów”, których opanowanie jest od niego wymagane. Ponadto powinny umożliwić studentowi kolejne przeczytanie tekstu z dużo większym stopniem jego zrozumienia. Niewątpliwie jednak także praca indywidualna i wiedza na temat danej dziedziny wyniesiona przez studenta $\mathrm{z}$ jego rodzimego systemu edukacji odgrywają istotną rolę $\mathrm{w}$ przyswajaniu fachowej leksyki.

\section{TECHNIKI NAUCZANIA SLOWNICTWA SPECJALISTYCZNEGO}

$\mathrm{Na}$ etapie prezentowania nowego słownictwa wykorzystywane są przede wszystkim następujące techniki: pokazanie ilustracji/konkretnego przedmiotu, przywołanie synonimu lub antonimu (jeśli to możliwe - internacjonalizmu), przywołanie definicji, kontekstowe objaśnienie znaczenia słowa, zilustrowanie znaczenia słowa za pomocą gestów/mimiki (Seretny, Lipińska 2005, s. 86). Wśród technik, które znajdują mniejsze zastosowanie w odniesieniu do zajęć z dziedziny architektury i historii sztuki, znajdują się: usytuowanie słowa na skali, podanie rodzimego odpowiednika, podanie definicji ze słownika. To, że prezentowanie obrazka lub konkretnego obiektu pojawia się tutaj na pierwszym miejscu, uwarunkowane jest ,naturą” nauczanego słownictwa. Słownictwo architektoniczne i słownictwo z dziedziny historii sztuki mają w dużym stopniu charakter konkretny, w drugiej kolejności dopiero pojawia się słownictwo abstrakcyjne (zob. Przybylska 2003, s. 211-212). Nie ulega wątpliwości, iż jest to coś, co ułatwia nauczanie słownictwa specjalistycznego na tym poziomie zaawansowania językowego. Trzeba ponadto dodać, że ze względu na narodowość studentów uczących się słownictwa architektonicznego i słownictwa z dziedziny historii sztuki często niemożliwe jest odwołanie się do ich rodzimego, z polskiej perspektywy egzotycznego języka, nierzadko także do języka angielskiego w dużej mierze nieznanego przez studentów. $Z$ drugiej strony należy zauważyć, że nawet w przypadku istnienia możliwości odwołania się do języka pośredniego nie zawsze jest to efektywna strategia - student może nie znać danego słowa w języku ojczystym czy też w języku angielskim, nawet jeśli wykazuje się zaawansowaną kompetencją językową. Odesłanie studenta do słownika w odniesieniu do słownictwa specjalistycznego także nie wydaje

rzezba-klasycystyczna-842.html; http://portalwiedzy.onet.pl/36139,,,,canova_antonio,haslo.html; http://encyklopedia.pwn.pl/haslo/Thorvaldsen-Bertel;3987196.html.

${ }^{15}$ Por. przyp. 11. 
się skuteczną metodą ze względu na stopień skomplikowania językowego i pojęciowego słownikowych definicji ${ }^{16}$.

Utrwalaniu i powtarzaniu leksyki służą następujące techniki nauczania: dopasowywanie wyrazów do definicji, podawanie synonimów, dopełnianie połączeń (Seretny, Lipińska 2005, s. 91, 94-96). Ponadto, ze względu na to, że ważny element zajęć stanowi czytanie ze zrozumieniem, w czasie kursu słownictwa architektonicznego i słownictwa $\mathrm{z}$ dziedziny historii sztuki stosowane są również takie techniki nauczania czytania jak: odpowiadanie na pytania, prawda/fałsz, kończenie zdań, wybór poprawnej odpowiedzi (Seretny, Lipińska 2005, s. 200-203).

Poniżej przedstawione zostały przykładowe zadania będące realizacją wymienionych technik.

Jak to się nazywa? Proszę napisać odpowiednie słowo.

1. relacja między światłem i cieniem na obrazie $\rightarrow$ światłocień

2. obraz prezentujący naturę $\rightarrow$

3. technika łagodnego przechodzenia od ciemniejszych kolorów do jasnych z jednoczesnym efektem ,zamglenia” $\rightarrow$

Co to jest? Proszę napisać definicje.

1. chryzelefantyna $\rightarrow$ technika rzeźbiarska, $w$ której części ciała byly robione z kości stoniowej, a szaty, wlosy i akcesoria ze zlota inkrustowanego szlachetnymi kamieniami

2. $\quad$ kontrapost $\rightarrow$

3. laserunek $\rightarrow$

Podkreślone słowa proszę zastąpić słowami z ramki (wyrazy o podobnym znaczeniu).

mniejsze, masywnych, strzeliste, ustiti, uformował się

W średniowiecznej Europie ludzie budowali wiele kościołów.

W średniowiecznej Europie ludzie wznosili wiele kościołów.

Sklepienia kościołów opierały się na ciężkich i grubych filarach i kolumnach.

Kościoły gotyckie to budowle „wysokie i szczupłe”.

Mury kościołów gotyckich są zredukowane.

Styl gotycki ukształtował się ze stylu romańskiego we Francji.

Słowa z kolumny A proszę połączyć ze słowami z kolumny B (wyrazy o podobnym znaczeniu).

\begin{tabular}{|l|l|}
\hline \multicolumn{1}{|c|}{ A } & a. kolor \\
1. śiecki & B. nieprawdziwy \\
3. pozorny & c. niereligijny \\
4. blady & d. nieintensywny \\
5. barwa & e. zbieżny \\
\hline
\end{tabular}

${ }^{16} \mathrm{Na}$ temat definicji słownikowych zob. np.: Apresjan 2000, s. 99-109, Grochowski 1982, s. 122-124, Grochowski 1988, Bartmiński, Tokarski 1993, Bednarek, Grochowski 1997, s. 36-38. Literatura poświęcona definiowaniu i definicjom słownikowym jest niezwykle bogata, stąd też przywołano tutaj jedynie kilka przykładowych prac dotyczących tego właśnie zagadnienia. 


\begin{tabular}{|c|l|l|l|l|}
\hline 1 & 2 & 3 & 4 & 5 \\
\hline $\mathrm{c}$ & & & & \\
\hline
\end{tabular}

Co pasuje? Do poniższych słów proszę dopisać słowa z ramki.

mitologiczne, świeckie, rodzajowe, linearna, eksperymentalne

1. malarstwo eksperymentalne

2. perspektywa

3. sprawy

4. sceny

5. motywy

Proszę odpowiedzieć na pytania.

Jak nazywają się trzy najważniejsze porządki architektoniczne starożytnej Grecji?

Sa to: porządek dorycki, joński, koryncki.

Co to były megarony?

Gdzie narodziła się technika malarstwa olejnego?

Proszę zdecydować, czy podane zdania są prawdziwe czy fałszywe.

\begin{tabular}{|l|l|l|}
\hline & Prawda & Fałsz \\
\hline Antyk trwał od XIII w. p.n.e. do V w. n.e. & & X \\
\hline Za koniec antyku uważamy datę urodzenia Chrystusa. & & \\
\hline Okres największego rozwoju cywilizacji greckiej to okres klasyczny. & & \\
\hline $\begin{array}{l}\text { Imperium Rzymskie zostało podzielone na dwie części (zachodnią } \\
\text { i wschodnią) w } 390 \text { r. }\end{array}$ & & \\
\hline Podstawą wierzeń starożytnych Greków i Rzymian była mitologia. & & \\
\hline
\end{tabular}

Proszę dokończyć zdania.

Dzisiaj mało wiemy o starożytnym malarstwie, bo zachowaty się tylko nieliczne starożytne dzieła malarskie.

Mozaika nie była popularna w średniowieczu, bo...

Popularnymi scenami w średniowiecznej rzeźbie były...

Proszę wybrać dobrą odpowiedź.

1. Styl romański narodził się w:

a. XII w. b. XI w. c. X w.

2. Styl romański bazował na koncepcjach architektonicznych:

a. starożytnego Rzymu i wczesnego chrześcijaństwa b. starożytnej Grecji i wczesnego chrześcijaństwa c. starożytnej Grecji i starożytnego Rzymu

3. Kościół w Bagneux to przykład:

a. stylu romańskiego b. stylu gotyckiego c. połączenia stylu romańskiego i gotyckiego 
Proszę zaznaczyć dobrą odpowiedź.

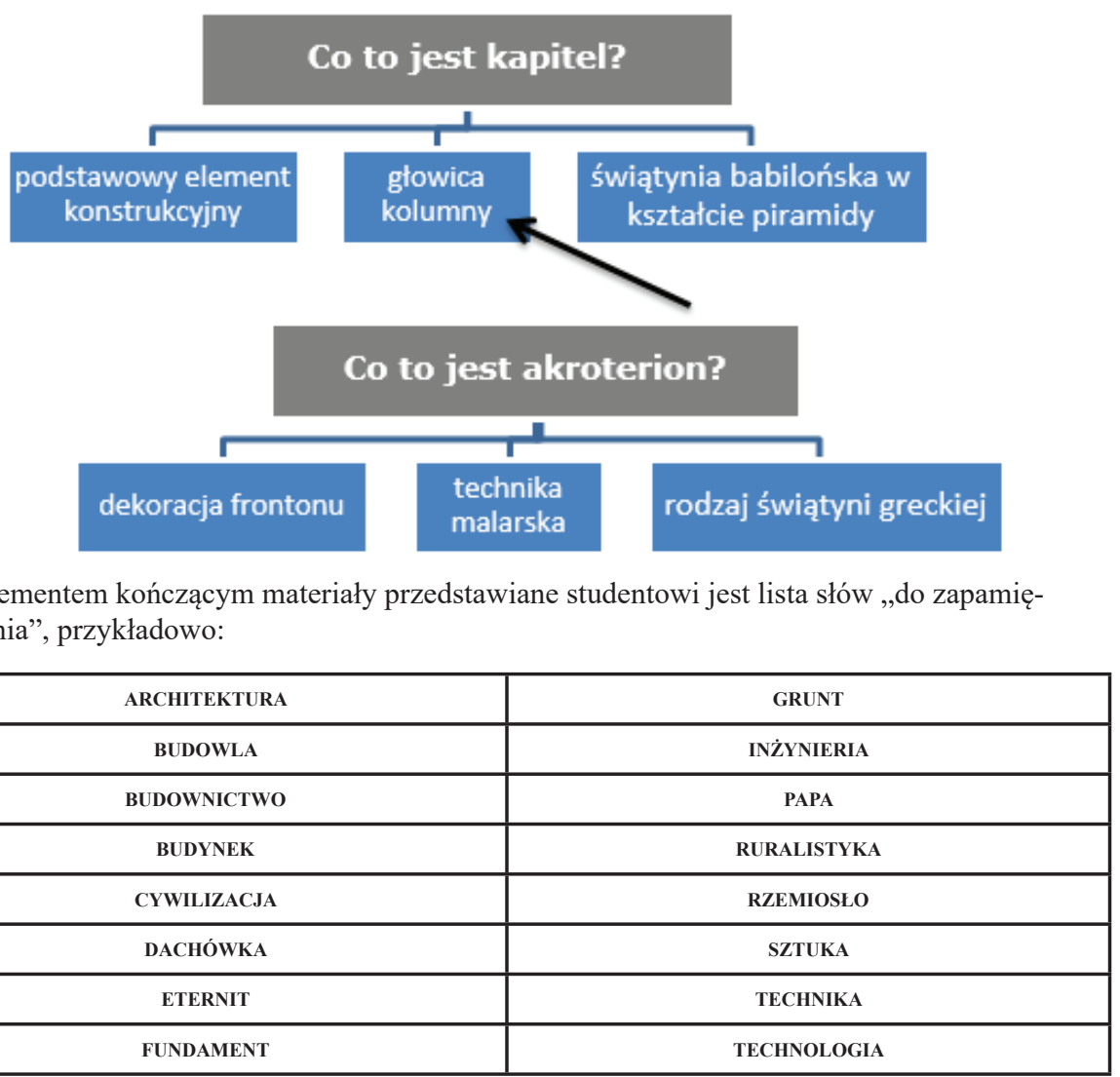

\section{TRUDNOŚCI ZWIĄZANE Z NAUCZANIEM SLOWNICTWA SPECJALISTYCZNEGO}

Nauczanie leksyki specjalistycznej w grupach na poziomie podstawowym A1 i A2 wiąże się z koniecznością zmierzenia się z różnego typu trudnościami. Przede wszystkim w obrębie danej grupy spotykają się studenci pochodzący z różnych krajów. W rezultacie grupa jest zróżnicowana pod względem „zaplecza” kulturowego. Pociąga to za sobą nieznajomość pewnych treści z zakresu kultury, które w trakcie edukacji przyswajają polscy uczniowie (przykładowo kultury starożytnych Grecji i Rzymu). Kolejną trudnością jest stopień opanowania języka polskiego. Mimo iż wszyscy uczą się na poziomie A1 lub A2, ich poziom znajomości języka jest zróżnicowany (np. studenci ukraińscy vs. studenci mongolscy). Nauczania słownictwa specjalistycznego nie ułatwia też 
nieznajomość leksyki tematycznej w rodzimych językach studentów. Trzeba jednak podkreślić, że nie zawsze jest to ich „wina”. Przyczyną bywają chociażby różnice między systemami edukacyjnymi, w których realizowane są niejednolite (nie zawsze zgodne z polskimi oczekiwaniami) treści nauczania. W konsekwencji jednak niemożliwe staje się takie nauczanie słownictwa specjalistycznego, w którym część zasobu leksykalnego mogłaby zostać opanowana za zasadzie nadawania polskich „etykietek” obiektom i pojęciom specjalistycznym znanym już studentowi z języka ojczystego.

Inną trudnością, o której trzeba tutaj wspomnieć, jest brak kompetencji ,językowo-intelektualnych". Chodzi mianowicie o kłopoty związane z definiowaniem, wyciąganiem wniosków, syntetyzowaniem tekstu, a więc o te kompetencje, które uwarunkowane są znajomością języka, ale także wykraczają poza jego opanowanie. Wśród trudności o podobnej naturze znajdują się problemy związane z interpretowaniem tekstu (czy raczej ,radzeniem sobie” z tekstem), ponadto z uczeniem się języka obcego „w ogóle”. Osobno należy wymienić trudności takie jak: brak zainteresowania tematem, brak motywacji, wreszcie brak koncentracji. Wszystko to sprawia, że realne efekty nauczania słownictwa specjalistycznego w grupach A nie zawsze pokrywają się z efektami oczekiwanymi. Za ilustrację niech posłużą tutaj poniższe autentyczne przykłady.

W jakim stylu zostat zbudowany kościót Mariacki w Krakowie? - Późny barok (student z Ukrainy).

Co to znaczy p.n.e. i od jakiego momentu datujemy n.e.? - Przed naszą erą, od urodzenia Kolumba (student z Angoli).

Prosze podać dwóch filozofów epoki antyku. - Leonardo da Vinci (student z Mongolii).

Jaka jest różnica między architektura romańska i gotycką? - Duży kolor, mały kolor (student z Mongolii).

\section{PODSUMOWANIE}

Kończąc rozważania, warto krótko zarysować losy niektórych absolwentów, choć niewątpliwie nie przesądzają one o pozytywnej ocenie samego kursu. I tak Wojtek Ogunsote (Nigeria) założył prywatne studio architektoniczne w Krakowie - „Ogunsote Studio”. Iman Kimiae (Iran) jest laureatem wielu polskich nagród architektonicznych, współpracuje też z prywatnymi firmami oraz z samą Politechniką Krakowską. Marina Polets (Kazachstan) uczestniczyła w licznych warsztatach w Polsce i za granicą (m.in. w Rosji, na Ukrainie, we Włoszech, w Szwajcarii), brała udział w konkursach międzynarodowych (m.in. w Turcji, Stanach Zjednoczonych, Kanadzie), pracuje w Mediolanie w biurze architektonicznym 
„RRC studio”. Marina Grishel (Białoruś) po studiach otrzymała pracę w jednym z krakowskich biur architektonicznych, wraz z koleżanką założyła także firmę graficzno-dekoracyjną „Przepis na Dizajn”.

Podsumowując, należy powiedzieć, że nauczanie studentów obcokrajowców słownictwa $\mathrm{z}$ danej dziedziny wiedzy stanowi w MCK PK jeden z elementów całościowego kształcenia o charakterze specjalistycznym. W ramach zajęć leksykalnych uczący się przyswajają nie tylko poszczególne wyrazy, ale także wiedzę, co jest związane ze specyfiką kursu, w którym uczestniczą. Ma on językowo i często także merytorycznie (ze względu na egzaminy wstępne) przygotować ich do studiowania na polskiej uczelni wyższej. Najważniejszym narzędziem dydaktycznym służącym realizacji tego celu jest tekst. Ćwiczenia, które mu towarzyszą, ilustrują wykorzystanie technik stosowanych w nauczaniu języka polskiego ogólnego.

Kurs słownictwa specjalistycznego to także różnego rodzaju trudności dydaktyczne. Wypracowanie skutecznych strategii radzenia sobie z nimi jest ważnym zadaniem stojącym przed zespołem nauczającym w jednostce. Podobnie jak rzetelna ocena skuteczności nauczania w odniesieniu do zajęć z leksyki architektonicznej i zajęć z dziedziny historii sztuki.

\section{BIBLIOGRAFIA}

Apresjan J. D., 2000, Semantyka leksykalna. Synonimiczne środki języka, Wrocław-WarszawaKraków.

Bartmiński J., Tokarski R. (red.), 1993, O definicjach i definiowaniu, Lublin.

Bednarek A., Grochowski M., 1997, Zadania z semantyki językoznawczej, Toruń.

Chłopicka-Wielgos M., Pukas-Palimąka D., 1996, Nauczanie języka specjalistycznego a nie tylko terminologii, „Acta Universitatis Lodziensis. Kształcenie Polonistyczne Cudzoziemców” nr 7/8, s. 69-80.

Gajewska E., Sowa M., 2014, LSP, FOS, Fachsprache... Dydaktyka języków specjalistycznych, Lublin.

Gałyga D., 2015, Skuteczność nauczania cudzoziemców języka polskiego jako obcego na przykładzie działalności Instytutu Polonijnego Uniwersytetu Jagiellońskiego w latach 1996-2004, Kraków.

Grochowski M., 1982, Zarys leksykologii i leksykografii. Zagadnienia synchroniczne, Torun.

Grochowski M., 1988, Podstawowe zasady definiowania wyrażeń w słowniku jednojęzycznym, w: W. Lubaś (red.), Wokót słownika współczesnego języka polskiego, Wrocław, s. 45-62.

Janowska I., Lipińska E., Rabiej A., Seretny A., Turek P. (red.), 2011, Programy nauczania języka polskiego jako obcego: poziomy A1-C2, Kraków.

Kic-Drgas J., 2015, Trudności w uczeniu się terminologii specjalistycznej, „e-mentor”, nr 3, s. $17-22$.

Komorowska H. (red.), 2003, Europejski system opisu ksztatcenia językowego: uczenie się, nauczanie, ocenianie, Warszawa.

Lesiak-Bielawska E., 2015, Potrzeby nauczycieli języków specjalistycznych a programy ksztatcenia i formy doskonalenia zawodowego, „Języki Obce w Szkole”, nr 3, s. 75-79. 
Ligara B., Szupelak W., 2012, Lingwistyka i glottodydaktyka języków specjalistycznych na przykładzie języka biznesu. Podejście porównawcze, Kraków.

Malinowska E., Nocoń J., Żydek-Bednarczuk U. (red.), 2013, Style wspótczesnej polszczyzny. Przewodnik po stylistyce polskiej, Kraków.

Polański K. (red.), 2003, Encyklopedia językoznawstwa ogólnego, Wrocław-Warszawa-Kraków.

Przybylska M., 2011, Zarys programu nauczania cudzoziemców języka specjalistycznego na przykładzie polskiego języka architektury, [praca magisterska], Kraków.

Przybylska R., 2003, Wstęp do nauki o języku polskim, Kraków.

Przybylska R., 2008, O potrzebie tworzenia korpusów tekstów do nauczania języka polskiego jako obcego, w: W. T. Miodunka, A. Seretny (red.), W poszukiwaniu nowych rozwiazań. Dydaktyka języka polskiego jako obcego u progu XXI wieku, Kraków, s. 31-34.

Seretny A., Lipińska E., 2005, ABC metodyki nauczania języka polskiego jako obcego, Kraków.

Starzec A., 2013, Styl popularnonaukowy - styl dyskursu popularnonaukowego, w: E. Malinowska, J. Nocoń, U. Żydek-Bednarczuk (red.), Style wspótczesnej polszczyzny. Przewodnik po stylistyce polskiej, Kraków, s. 71-110.

Zdunkiewicz-Jedynak D., 2013, Wyktady ze stylistyki, Warszawa.

Żydek-Bednarczuk U., 2013, Dyskurs internetowy, w: E. Malinowska, J. Nocoń, U. Żydek-Bednarczuk (red.), Style współczesnej polszczyzny. Przewodnik po stylistyce polskiej, Kraków, s. $347-379$.

http://elf2.pk.edu.pl/course/view.php?id=736 [13.03.2017].

\section{ANEKS}

Słownictwo architektoniczne - końcowy test zaliczeniowy

Imię i nazwisko:

Liczba punktów: $/ 30 \mathrm{p}$.

\section{Proszę odpowiedzieć na pytania.}

0 . Co to jest architektura i czym się zajmuje?

Architektura jest dyscyplina, która zajmuje się organizowaniem i ksztaltowaniem przestrzeni oraz jej dostosowywaniem do danych funkcji.

1. Co to jest budownictwo i czym się zajmuje?

2. Od kiedy i do kiedy datujemy barok i renesans?

barok -

renesans - 
3. Czym może być pokryty dach?

- dachówka

•

/ 1 p. $(2 \times 0,5$ p. $)$

4. Jakie cechy charakterystyczne ma kolumna jońska?

- żłobkowany trzon z 24 kanelami

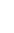

/ 4 p. $(4 \times 1$ p. $)$

5. Jakie dwa style architektoniczne rozwinęły się w średniowieczu?

- $\quad$ styl romański

$$
/ 0,5 \text { p. }(1 \times 0,5 \text { p. })
$$

6. Jakie budowle najczęściej budowano w antyku (Grecja i Rzym)?

- światynie

(1)

$$
\text { / } 1,5 \text { p. }(3 \times 0,5 \text { p. })
$$

\begin{tabular}{|c|c|}
\hline $\begin{array}{l}\text { architektura gotycka: } \\
\text { - kamień i cegła jako główny materiał budowlany } \\
\text { - } \\
\text { - }\end{array}$ & $\begin{array}{l}\text { architektura romańska: } \\
\text { - kamień jako główny materiał budowlany } \\
\text { - } \\
\text { - }\end{array}$ \\
\hline
\end{tabular}

7. Czym różni się architektura gotycka od architektury romańskiej? 
8. Jaki to styl?

0. modernizm
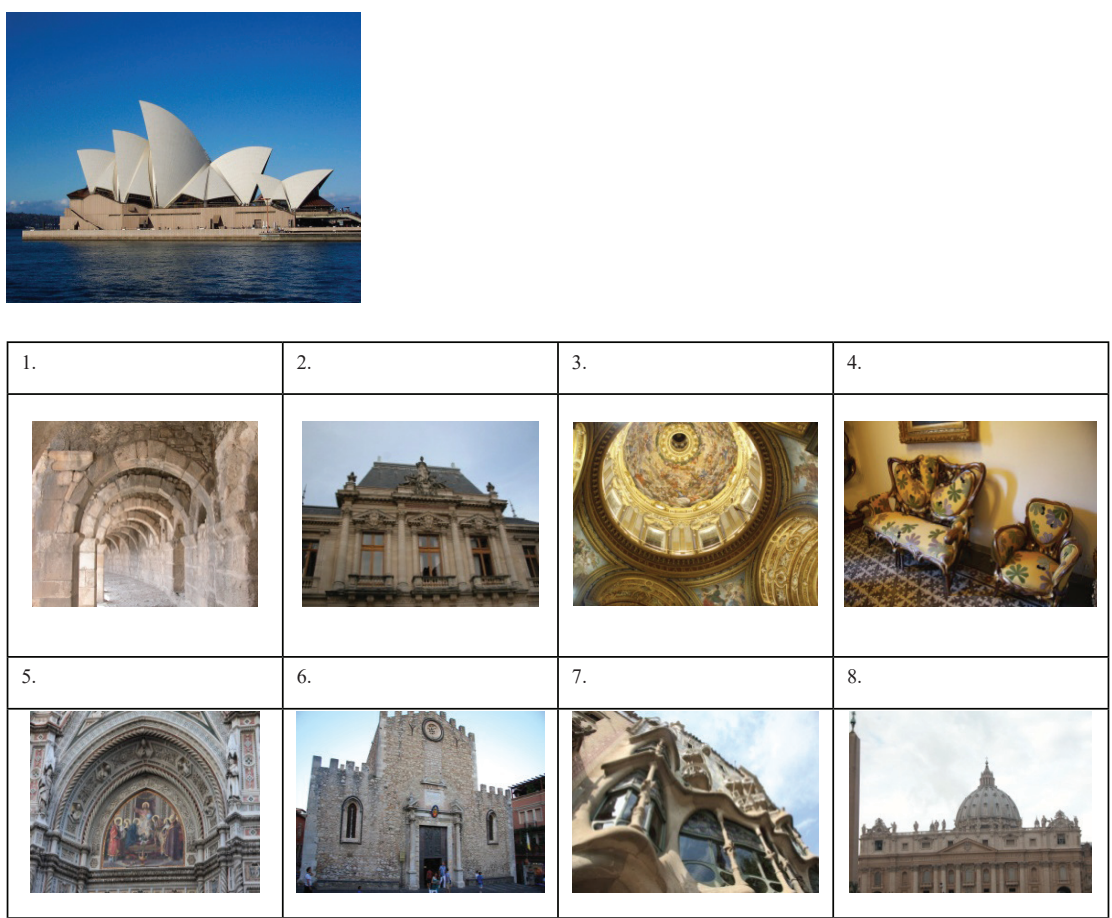

$/ 4$ p. $(8 \times 0,5$ p. $)$

II. Proszę wymienić trzy cechy charakterystyczne dla baroku.

- monumentalne budowle

III. Proszę wymienić trzy style architektoniczne XX wieku.

- $\quad k u b i z m$

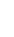

(1) 
IV. Proszę wymienić trzy typy dachów.

- polski

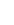

/ $1,5 \mathrm{p} .(3 \times 0,5 \mathrm{p}$.

V. Proszę wymienić trzy materiały budowlane.

- cegta

-

(1)

L $1,5 \mathrm{p} .(3 \times 0,5 \mathrm{p}$.

VI. Proszę zaznaczyć na rysunku: schody, ścianę działową, ścianę nośną.

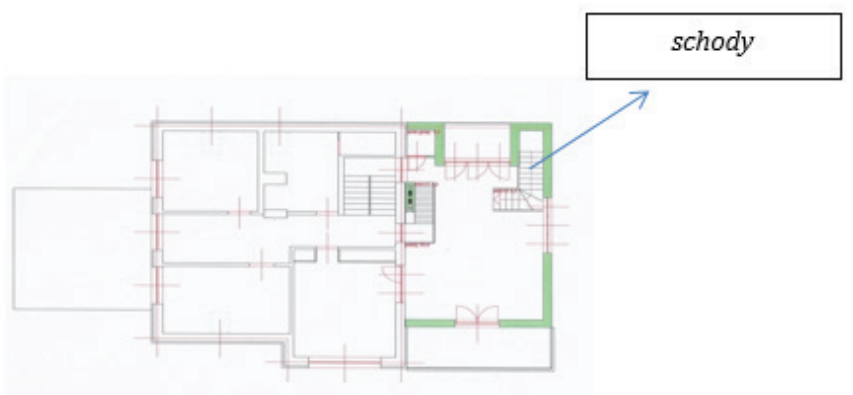

/ 1 p. $(2 \times 0,5$ p. $)$

VII. Proszę zaznaczyć na fotografii: portal, rozetę, archiwoltę, biforia.

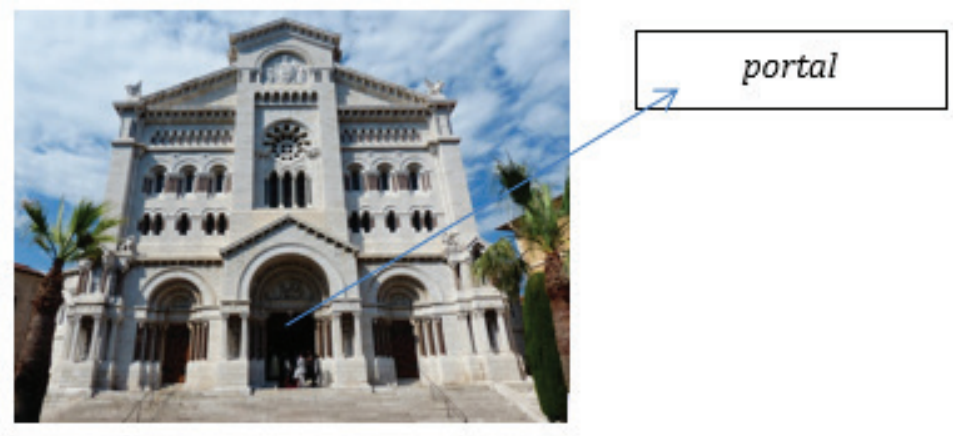

$/ 1,5$ p. $(3 \times 0,5$ p. $)$ 


\section{Rozwiązanie testu}

I.

1. Dziedzina działalności człowieka związana ze wznoszeniem obiektów budowlanych. Zajmuje się też ich przebudową, odbudową i modernizacją.

2. Barok - od końca XVI, XVII i pierwszej połowy XVIII wieku, renesans - od XIV do XVI wieku.

3. Eternitem, gontem.

4. Smukła kolumna, woluta, lekkie, smukłe proporcje, baza oparta na plincie.

5. Styl gotycki.

6. Akwedukty, teatry, łaźnie.

7.

\begin{tabular}{|l|l|}
\hline architektura gotycka: & architektura romańska: \\
strzeliste budynki & masywne budynki \\
duże okna z witrażami & małe okna niewpuszczające światła \\
sklepienie krzyżowo-żebrowe & sklepienie kolebkowe \\
\hline
\end{tabular}

8. Antyk, renesans, barok, secesja, gotycki, romański, secesja, renesans/barok.

II. Dynamizm, bogata sztukateria, ciężkie proporcje, dynamika budynku.

III. Socrealizm, modernizm, surrealizm.

IV. Mansardowy, czteropołaciowy, dwupołaciowy, kopertowy.

V. Drewno, szkło, beton.

VI.

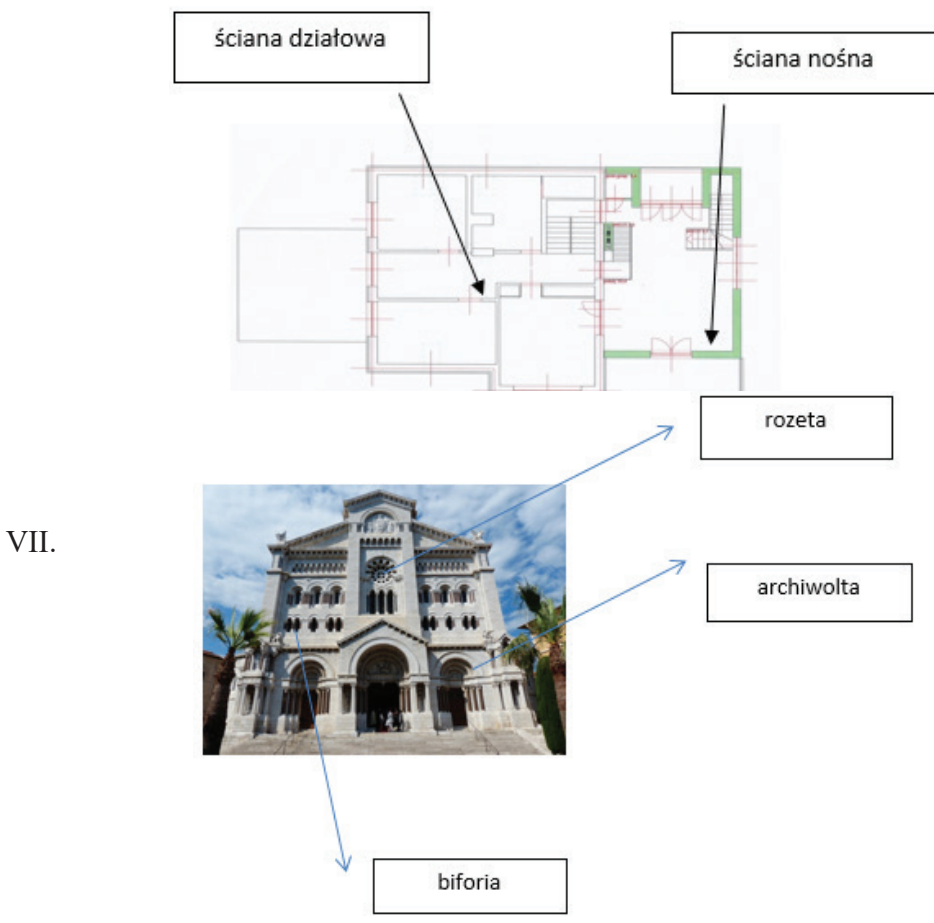


Rozwiązanie ćwiczeń

Ćw. 1: Pejzaż, sfumato.

Ćw. 2: Poza, w której postać opiera się na jednej nodze, a ciężar ciała jest równoważony wygięciem sylwetki w kształcie litery „S”; transparentna lub półtransparentna warstwa farby, która zmienia kolor niższych warstw obrazu, przede wszystkim olejnego.

Ćw. 3: Masywnych, strzeliste, mniejsze, uformował się.

Ćw. 4: 2e, 3b, 4d, 5a.

Ćw. 5: Perspektywa linearna, sprawy świeckie, sceny rodzajowe, motywy mitologiczne.

Ćw. 6: Budowla na planie prostokąta, z przedsionkiem, bez okien, z drewnianymi słupami, które podtrzymywały strop, podstawa rozwoju starożytnej architektury greckiej; w Niderlandach.

Ćw. 7: Fałsz, prawda, fałsz, prawda.

Ćw. 8: ... bo była techniką czasochłonną i zbyt drogą; ... Zesłanie Ducha Świętego, Wniebowstąpienie, Sąd Ostateczny, sceny z ksiąg Starego i Nowego Testamentu, Chrystus z ewangelistami.

Ćw. 9: Dekoracja frontonu.

Ćw. 10: 1c, 2a, 3c.

Edyta Gałat, Michalina Rittner

\section{TEACHING SPECIALIZED LEXIS AT THE INTERNATIONAL CENTRE OF EDUCATION OF THE CRACOW UNIVERSITY OF TECHNOLOGY TO THE GROUPS OF ELEMENTARY LEVEL A1 AND A2 (BASED ON THE ARCHITECTURE AND HISTORY OF ART VOCABULARY)}

Keywords: specialized vocabulary, elementary level A1 and A2, architecture, history of art

Summary. The article presents the "model" of teaching specialized vocabulary in elementary (A1 and A2) level groups, which has been developed at the International Centre of Education of the Cracow University of Technology. As the example illustrating this ,model“ served the courses in architecture and history of art vocabulary. The first part of the text presents the most important information concerning the organization of the specialized vocabulary course. The rest of the article is devoted to the role of the text in the specialized vocabulary class at the MCK PK. It shows teaching techniques used in courses and cites examples of exercises. The text ends with a brief description of the difficulties which may arise during the teaching of specialized vocabulary in A level groups and description of successful graduates of the course carried out in the MCK PK. 